\title{
Experimental study of amniotic membrane or topical propolis on induced cutaneous wound healing in Wistar rats
}

\author{
Estudo experimental do uso da membrana amniótica e da própolis tópica na \\ cicatrização de feridas cutâneas induzidas em ratos Wistar
}

\author{
Rafaela Eduarda dos Reis ${ }^{1^{*}}\left(\mathbb{D}\right.$, Letícia da Silva Rueda ${ }^{(\mathbb{D})}$, Bruno Roberto Vidal Tuani ${ }^{1}$ (D), \\ Cláudia Sampaio Fonseca Repetti ${ }^{1}$ (D), Camila Dias Porto ${ }^{1}$ (1) , Daniel de Bortoli Teixeira ${ }^{1}$ (])
}

\begin{abstract}
The study of propolis and the amniotic membrane as alternatives to promote the acceleration of healing has grown considerably. These products have shown to be easy to use, have bactericidal or bacteriostatic action and are affordable. The objective of the present study was to evaluate the action of the amniotic membrane of bitches and propolis in the healing of surgical wounds. To evaluate the efficacy of these methods the time for conclusion of the healing process of both groups was compared with a control group. In addition, the inflammatory response of each group was also evaluated to identify which alternative method could induce a better response in the healing process compared to the control group. For this purpose, 27 animals, Rattus norvegicus, variety Wistar, were used. Rats were separated into 3 groups with 9 animals each. Group I represented the 25\% alcoholic propolis solution; Group II, Amniotic membrane; Group III was Control group. Wounds were assessed macroscopically for the lesion area, and microscopically for the histological quality of each wound layer and the intensity of inflammation and collagen deposition. After the macroscopic analysis, it was observed that there were no statistical differences among the 3 groups $(p>0.05)$ relevant to accelerate the healing process in terms of presence of inflammatory cells, fibroblasts, collagen, neovascularization, granulation tissue and re-epithelialization.
\end{abstract}

KEYWORDS: Healing; Alternative methods; Surgery; Reepithelization.

RESUMO: O estudo da própolis e da membrana amniótica como alternativa para promover a aceleração da cicatrização vem crescendo bastante, numa tentativa de buscar métodos alternativos para cicatrização de feridas que apresentem fácil utilização, ação bactericida ou bacteriostática e tenha custo acessível. Com o presente estudo objetivou-se avaliar a ação da membrana amniótica de cadelas e da própolis na cicatrização de feridas cirúrgicas, comparando o tempo no processo de cicatrização com o grupo controle e a resposta inflamatória de cada um, de maneira a identificar qual método alternativo induzirá melhor resposta no processo de cicatrizaçáo em comparação ao grupo controle. Para tanto, foram utilizados 27 animais, Rattus norvegicus, variedade Wistar, separados em três grupos com nove animais cada, sendo Grupo I - solução alcoólica de própolis a 25\%; Grupo II - Membrana amniótica de cadelas; Grupo III - Grupo controle. As feridas foram avaliadas macroscopicamente quanto à área da lesão, e microscopicamente quanto à qualidade histológica de cada leito da ferida e à intensidade de inflamação e deposição de colágeno. Após a análise macroscópica, constatou-se que não houve diferenças estatísticas ( $>00,05)$ relevantes para acelerar o processo cicatricial, quanto a presença de células inflamatórias, fibroblastos, colágeno, neovascularização, tecido de granulação e reepitelização, perante os tratamentos alternativos e o grupo controle no processo de cicatrização.

PALAVRAS-CHAVE: Cicatriz; Métodos alternativos; Cirurgia; Reepitelização.

\section{INTRODUCTION}

The study of complementary methods that stimulate wound healing is necessary due to the high number of cases the presents this condition in the veterinary medical routine. Some characteristics such as capacity of acceleration of healing process, bactericidal action and affordable cost are desired when using these products. Among the available alternative methods, propolis and amniotic membrane are considered interesting choices for their ability to stimulates tissue repair, and for being affordable.

During the healing process, neutrophils and monocytes migrate to the wound. Their main function is to produce growth 
factors that prepare the wound for the proliferative phase, when fibroblasts and endothelial cells are recruited (FERREIRA, 2016). The proliferative phase is responsible for the closure of the lesion and is marked by fibroplasia, angiogenesis and reepithelization (SUVARNA et al., 2013). Optimal healing depends on increased granulation, tissue formation, increased fibroblastic proliferation and synthesis of extracellular matrix components, especially collagen (PACHECO, 2016). It has been noted in several alternative healing methods that the acceleration of the healing process usually occurs by the reduction of the inflammatory phase, which makes fibrosis and collagen deposition faster (TAGLIARI et al., 2019).

Propolis is widely used in the treatment of wounds. It has potential to repair, reduce the healing time, increase the contraction of the wound and accelerate tissue repair process (PEREIRA; BÁRTOLO, 2016). It stands out as a phytotherapeutic alternative (BARACHO et al., 2016) for its easy use, harmlessness, low cost and healing power. In addition, it has bactericidal, bacteriostatic, antifungal and anti-inflammatory actions. These potentials are attributed to the resin composition of propolis with flavonoids and phenolic acids (MOREIRA et al., 2018). Propolis accelerates the transformation of fibrocytes into fibroblasts (PAIXÃO et al., 2014). Likewise it contains chemical elements such as iron and zinc, which are relevant for collagen synthesis. In addition, propolis also contains amino acids (arginine and proline) that can be used as raw material for protein synthesis and act to stimulate cell mitosis (RIBEIRO et al., 2013).

Hozzein et al. (2015) induced experimental wounds in rats with Diabettes Melitus. These animals were treated with propolis alcohol extract for 15 days. The results of the treatment were reduction in healing time and increase in collagen production when compared to the control group which was treated with $0.9 \%$ saline solution.

Marinho (2018) used a combination of laser therapy and green propolis in wounds experimentally induced in diabetic Wistar rats. In the study it was observed a shorter healing time. In addition, there was less degranulation of mast cells, increased vascular density, greater collagen organization and greater density of myofibroblasts. Nogueira et al. (2018) evaluated wound healing in rats inoculated or not with Staphylococcus aureus and treated with propolis, saline and clindamycin. In the study, it was identified that the group whose wound was aseptic and had been treated with propolis achieved complete healing on the $21^{\text {st }}$ day. Whereas, the other comparative groups did not show complete healing until the end of the study period. In conclusion, propolis has showed a good alternative method for healing aseptic wounds.

The amniotic membrane has immunological characteristics and can also be used as an epidermis reservoir. Thus, it contains fibroblast and cytokine growth factors that modulate inflammation, which could improve the healing process (HUNGER et al., 2019). The application of the amniotic membrane to a wound prevents dissection and excessive loss of fluids. Additionally, it provides analgesic effect, and protects nerve endings exposed to the environment. Likewise, it has anti-inflammatory, antibacterial, antiviral, and immunological characteristics, and stimulates epithelialization (MAMEDE et al., 2012). Leila et al. (2017) conducted a randomized clinical trial with the objective of understand the effect of the amniotic membrane graft on the healing process after anal fistulotomy in humans. After wound analysis, it was noted that healing rate was approximately $67 \%$ in the intervention group (with an amniotic membrane graft) and about $54 \%$ in the control group. Thus, the authors concluded that the amniotic membrane accelerates wound healing. In addition, a study conducted by Reis Filho et al. (2017) demonstrated that the canine amniotic membrane in association with skin grafts in rabbits caused an intense inflammatory reaction. However, it appeared to prevent graft nutrition, thus, it would not be indicated for this purpose.

Propolis and amniotic membrane have potential to help in the healing process and understanding the effectiveness of using these methods on wounds in detriment of other treatments is important. Therefore, the objective of this study was to evaluate the action of the propolis and amniotic membrane by comparing the time of healing process with the control group, and analyzing the inflammatory response of each treatment. In addition, this study aimed to identify which alternative method induced the best response in the healing process.

\section{MATERIAL AND METHODS}

The research was conducted at the Veterinary Hospital "Vicente Borelli”, of the Faculty of Veterinary Medicine of UNIMAR, Marília, state of São Paulo. This study was approved by the Ethics Committee on Animal Use (CEUA / UNIMAR) on October 5, 2018.

For the experiment, 27 male Wistar rats, with approximately $230 \mathrm{~g}$ of weight, were used. These animals were obtained from the Animal Models Experimentation Center of UNIMAR. The rats were housed in individual cages $(40 \times 30 \times 17 \mathrm{~cm})$, and maintenance of welfare was made with the addition of pine shavings water and commercial feed were offered ad libitum.

In this study, $25 \%$ of green propolis was manufactured on the institution's farm was used. The amniotic membrane used in the present study was collected aseptically after cesarean sections performed at the educational institution, with subsequent washing with $0.9 \%$ saline and storage in $12 \%$ glycerin at room temperature (PONTES et al., 2008).

The animals were randomly divided into 3 groups $(\mathrm{n}=9$ / group). In addition, were divided into: Group I (Propolis). This group received the $25 \%$ alcoholic propolis solution over the surgical wound as treatment; Group II (Amniotic membrane). In this group, the amniotic membrane of a female dog was applied on the wound; Group III (Control group). 
in the group in which animals only had the wound cleaned daily with $0.9 \%$ saline solution.

For wound creation, all rats were subjected to dissociative anesthesia with tiletamine and zolazepam at a dose of $40 \mathrm{mg} /$ $\mathrm{kg}$, intraperitoneally. The area was shaved and local antisepsis with $0.5 \%$ chlorhexidine was performed. With a scalpel with a 15 blade, a rectangular surgical wound was created in the dorsal region of the animals measuring $1.5 \times 1.5 \mathrm{~cm}$ and $0.5 \mathrm{~cm}$ deep, which were measured with a surgical ruler. After the wound was performed, those animals belonging to the Propolis Group and the Control Group were placed individually in their cages. In the animals of the Amniotic Membrane Group, the membrane was affixed with a separate simple suture with 4-0 nylon around its margin over the entire wound at the time of the surgery. Animals were subsequently placed in individual cages. The amniotic membrane was properly preserved in a $12 \%$ glycerin solution and, prior to use, it was hydrated with $0.9 \%$ saline solution in a sterile tray. After the surgery, all groups received tramadol hydrochloride at a dose of $7.5 \mathrm{mg} / \mathrm{kg}$ intramuscularly.

For group I, propolis was applied directly over the entire wound in a single daily application, after cleaning with $0.9 \%$ saline. In group II, the wound was cleaned with $0.9 \%$ saline solution in a single daily application. For group III, the animals would have only cleaning the wound with sterile gauze and $0.9 \%$ saline solution in a single daily application. The animals received the mentioned treatments until euthanasia.

Euthanasia happened at 7,14 and 21 days of treatment in order to macroscopically assess the characteristics of the lesion in terms of size, color of the wound, presence of scabs and reepithelization with hair growth. Measurement of the wound area was performed with a caliper for subsequent comparison of all periods, obtaining the area of each wound using the formula of the area of the rectangle (base multiplied by height). The objective of the microscopic analysis was to evaluate the histological quality of each wound treated in terms of the level of inflammation and collagen deposition. On each of the days described 3 animals from each group were euthanized with intraperitoneal thiopental at a dose of $40 \mathrm{mg} / \mathrm{kg}$, without measuring the other live animals.

All euthanized animals were sent to the Animal Pathology laboratory for tissue collection and histopathological evaluation. The entire area of the healed wound (edges and central region), after being measured with a caliper, was excised, and fixed in a $10 \%$ formaldehyde solution. Thus, a total of 27 samples composed by 9 period samples ( 3 animals per group in each period analyzed) were subjected to the usual histological processing and included in paraffin. Hematoxylin and eosin (H.E.) and Masson's trichrome staining techniques were used.

Histopathological analysis was performed blindly by a pathologist. Quantitative assessment was carried out comparatively between the three assessment periods, known to be established in similar studies, as used by Martins et al. (2006) and Beheregaray et al. (2014). Values from 0 to 3 were applied to all variables. The following parameters were classified as absent (grade 0), mild (grade 1), moderate (grade 2) and grade (grade 3): presence of inflammatory cells (polymorphonuclear cells, macrophages, lymphocytes, mast cells), presence of fibroblasts, collagen, neovascularization, granulation tissue and reepithelization. The slides stained in H.E. were used to evaluate inflammatory cells, fibroblasts, vascularization, and reepithelization. Collagen deposition and granulation tissue organization were evaluated with Masson's trichrome stain.

The macroscopic data were submitted to analysis of variance (Two-way ANOVA) for evaluation of the effect of treatments, the effect of time and the interaction between treatment and time. In the presence of a significant effect, the averages were compared using the Tukey test at $5 \%$ probability. The assumptions of analysis of variance, normality of residues and homoscedasticity of variances were assessed, respectively, using the Shapiro-Wilk and Bartlett test, both at 5\% probability (data not shown). For the microscopic variables, KruscalWallis tests were used with Dunn's post-test at $5 \%$ probability. The data were analyzed in the GraphPad Prism 7.0 program, as well as the graphs and figures constructed in the same program.

\section{RESULTS AND DISCUSSION}

There was no significant effect of the interaction between treatments and time ( $p>0.05)$ (Table 1). There was also no significant difference ( $p>0.05$ ) between the means of the groups, being found the values of 0.29 (Propolis Group), 0.40 (Amniotic Membrane Group), 0.343 (Control Group).

At 7 days after surgery, the wounds exhibited similar morphology in all 3 experimental groups. The wounds had an average of $0.756 \mathrm{~cm}^{2}$ of total area, dry aspect, no secretion, brownish color, and thick crust formation (Figure 1-A, 1-D and $1-G)$. The average wound area for the Propolis Group was of $0.807 \mathrm{~cm}^{2}$, for the Amniotic Membrane Group was of $0.713 \mathrm{~cm}^{2}$ and for the Control Group was of $0.747 \mathrm{~cm}$.

At 14 days after the proceeding, the wounds showed a different morphology among groups. The Propolis Group had a small lesion area, without secretion, yellowish-white color and no presence of crust (Figure 1-B); Both Amniotic Membrane and Control Groups showed an area of about 50\% lesion, dry wound, no secretion, dark color and thick crust formation (Figure 1-E and 1-H). The average wound area was $0.047 \mathrm{~cm}^{2}$ for the Propolis Group, $0.363 \mathrm{~cm}^{2}$ for the Amniotic Membrane Group and $0.183 \mathrm{~cm}^{2}$ for the Control Group.

At 21 days post-surgery, the wounds of the animals of the Propolis Group were fully healed (Figure 1-C). However, the animals of the Amniotic Membrane Group, still presented a lesion area of about $25 \%$, dry aspect of the wound, no secretion, dark color and with thick crust formation (Figure 1-F) with an average wound area of $0.123 \mathrm{~cm}^{2}$. The Control Group wounds revealed a small extension lesion, with no secretion, 
Table 1. Averages resulting from the area $\left(\mathrm{cm}^{2}\right)$ of wound in each treatment.

\begin{tabular}{l|c|c|c|c} 
& $7^{\text {th }}$ day & $\mathbf{1 4}^{\text {th }}$ day & $\mathbf{2 1}^{\text {st }}$ day & Average \\
\hline Propolis Group & $0,807 \pm 0,411$ & $0,047 \pm 0,047$ & $0,017 \pm 0,012$ & $0,290 \pm 0,439 A$ \\
\hline Membrane Group & $0,713 \pm 0,061$ & $0,363 \pm 0,265$ & $0,123 \pm 0,127$ & $0,400 \pm 0,298 \mathrm{~A}$ \\
\hline Control Group & $0,747 \pm 0,216$ & $0,183 \pm 0,104$ & $0,100 \pm 0,020$ & $0,343 \pm 0,327 \mathrm{~A}$ \\
\hline Average & $0,756 \pm 0,238 a$ & $0,198 \pm 0,199 \mathrm{~b}$ & $0,080 \pm 0,081 \mathrm{~b}$ & \\
\hline
\end{tabular}

Averages followed by the same letters do not differ by Tukey's test $(P<0.05)$.

7th day.
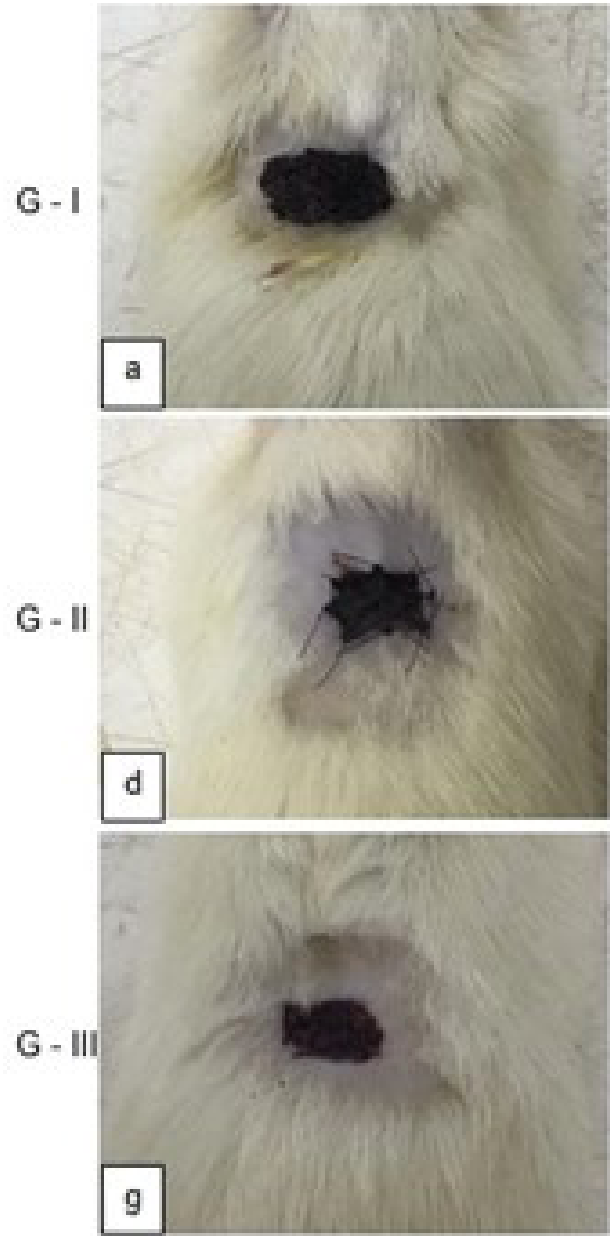

14th dax
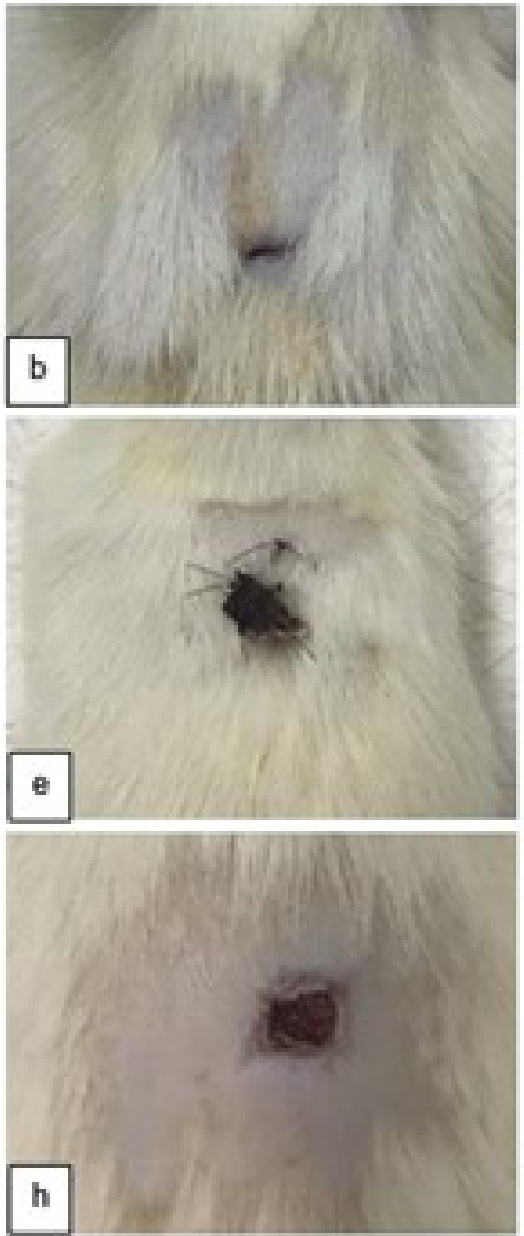

21 st day
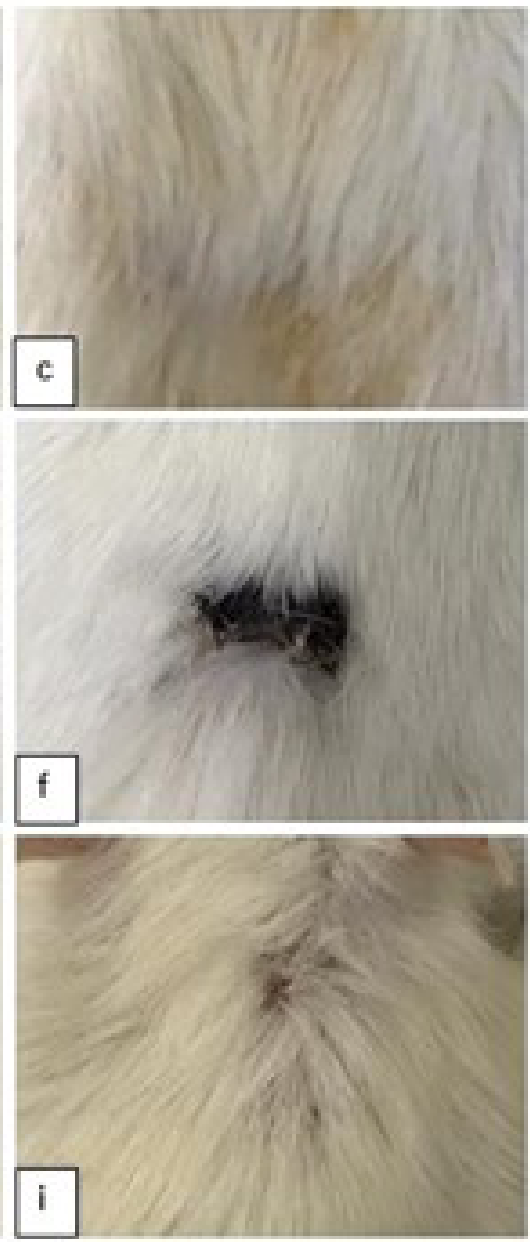

Figure l. Photographs illustrating the clinical evolution of the wounds performed on Rattus novergicus in three different groups of different treatments and in three moments of macroscopic evaluation. A) Macroscopic appearance of the wound on the seventh postoperative day (PO) of the animal in group I - propolis. B) Fourteenth PO day of group I - propolis. C) Twenty-first PO day of group I - propolis. D) Seventh PO day of group II - membrane. E) Fourteenth PO day of group II - membrane. F) Twenty-first PO day of group II - membrane. G) Seventh PO day of group III - control. H) Fourteenth PO day of group III - control. I) Twenty-first PO day of group III - control.

light color and no crust formation (Figure 1-I) with an average wound area of $0.1 \mathrm{~cm}^{2}$.

It is important to note that the Propolis Group was the only one that showed total healing on average on the 19th day of study, while the other comparative groups did not show complete healing until the 21 st postoperative day, demonstrating macroscopically fibrous scar tissue (granulation tissue). In the study conducted by Marinho et al. (2018) better macroscopic results of wound healing were observed in the groups in which propolis was used.

As demonstrated in Table 1, there was no statistical difference between the groups tested. This result agrees with what was observed by Duarte (2007). In his study, the researcher compared the healing process of induced wounds in the control group with a group treated with amniotic membrane. There were no significant statistical differences. In addition, 
it was observed a greater inflammatory process in some animals treated with the membrane, with areas of necrosis being found in the wounds. The author's result was explained by the microscopic observation of the reabsorption of the membrane by phagocytes. Also, greater healing activity was detected, probably due to the stitches of fixing nylon on the membrane (RIBEIRO et al., 2005).

In our study, the macroscopic analysis revealed that there was no statistical difference ( $p>0.05$ ) in the reduction of wound area when comparing both alternative methods with the control group. Other studies comparing biological membrane and propolis (Barbosa et al., 2009; Marquele-Oliveira et al., 2019) observed similar results, no presence of relevant improvement in the healing time or in the process when using the treatments. In figure 1, it is possible to compare the wounds macroscopically for each alternative method and the days that have elapsed.

\section{Inflammatory cells}

In all analyzed periods, there was no statistical difference ( $p>0.05$ ) between the groups regarding the presence of polymorphonuclear cells. This fact contradicts the antigenic action of the amniotic membrane reported in the literature (HUNGER et al., 2019).
The Control Group, exhibited less presence of macrophages compared to the other groups studied ( $p=0.043$ ) at 7 days postoperatively (Figure $2-\mathrm{A}$ ). In the analyzes at 14 and 21 days after surgery, there was no statistical difference between the groups ( $p>0.99)$.

Regarding inflammatory cells, neutrophils are the first cells responsible for phagocyting and destroying pathogenic microorganisms. The action of these cells lasts approximately 48 hours after the beginning of the healing process. Then, these cells are replaced by macrophages (FREITAS, 2018). Endothelial proliferation is a fundamental process in the healing mechanism. This process depends on the presence of macrophages, which promote neoangiogenesis due to interactions with prostaglandins and thromboxanes (GARROS et al., 2006). In view of this, both alternative methods showed a marked presence of macrophages in the initial analysis compared to the control group.

The analyzed groups showed statistical difference at 7 days post- surgery (Figure 2-B), showing a marked presence of lymphocytes in the Propolis Group compared to the other groups $(\mathrm{p}=0.043)$. In the analyzes at 14 and 21 days after surgery, no statistical difference was observed between the groups ( $p>0.30)$. The role of lymphocytes in healing is not well defined and remains controversial. It is known that because of the presence lymphokines such as interleukin-2
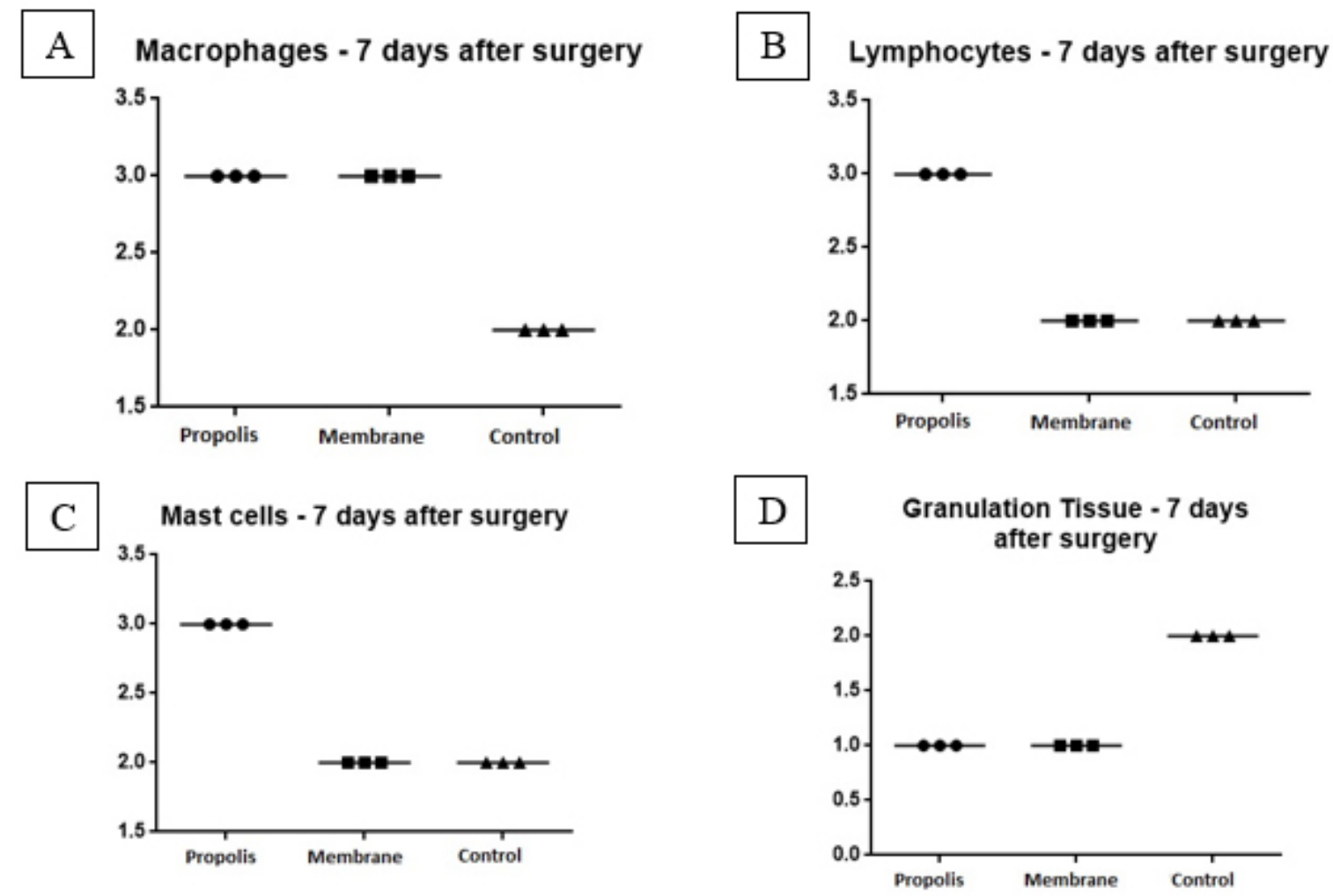

Figure 2. Variation of changes in macrophages, lymphocytes, mast cells and granulation tissue in the Propolis, Amniotic Membrane and Control groups during the treatment period employed. A) Macrophages at 7 days postoperatively (PO). B) Lymphocytes at 7 days PO. C) Mast cells at 7 days PO. D) Granulation tissue at 7 days of $P O$. 
and macrophage activation factor (MAF), these cells have an important influence on macrophages, endothelial cells, and fibroblasts (MANDELBAUM et al., 2003).

The groups showed a statistical difference at 7 postoperative days (Figure 2-C). It was observed a greater number of mast cells in the Propolis Group compared to the other groups $(\mathrm{p}=0.043)$. In the $14^{\text {th }}$ day and $21^{\text {st }}$ day analyzes, no statistical difference was observed between the groups ( $p>0.99$ ). Differently from what was noted, a study using topical application of propolis observed less mast cell count, which may have accelerated the healing process and decreased inflammation (ORYAN et al., 2018). This theory does not support the findings of the present study, since Group I - Propolis showed an increase in these cells on the $7^{\text {th }}$ postoperative day.

\section{Fibroblasts}

It was not observed significant difference between the groups regarding the presence of fibroblasts $(p>0.26)$ in any of the post-surgery days. This result does not agree with Paixão et al. (2014). Their study observed that propolis was effective in accelerating the reversal of fibrocytes in fibroblasts during the first 7 days (post- surgery?). In addition, propolis seemed to have reactivated synthesis capacity of these cells. On the other hand, in the control group of the same study, it was observed an increase in fibroblasts starting on the $14^{\text {th }}$ day, which suggests a delayed tissue repair.

\section{Collagen}

No statistical difference was observed regarding the presence of colagen among the groups in all studied periods ( $p>0.06$ ). Although the amniotic membrane is rich in collagen, it did not interfere with the production of this component by the wound (HORTENSIUS et al., 2016). Propolis has been shown to be efficient in stimulate the expression of type I collagen during the initial healing stage, which promotes rapid wound contraction (ALMEIDA et al., 2013; JASTRZęBSKA-STOJKO et al., 2013). However, in the present study, no statistical difference was observed, which in agreement with the findings of the aforementioned authors.

\section{Neovascularization}

No statistical difference was observed regarding neovascularization in all time points ( $p>0.06$ ). Bovino et al. (2017) carried out a study comparing thermography in wound healing in rabbit limbs. In the study, groups were treated with $0.9 \%$ saline solution or amniotic membrane. Higher temperature values are observed when there is greater cutaneous blood flow. During the healing process in the study by Bovino et al, (2017) it was not observed thermographic difference between the groups studied. In addition, a study conducted by Marquele-Oliveira et al. (2019), had 3 different treatments: biocellulose membranes embedded in propolis, cellulose membranes and control. The study demonstrated that there were no differences between the groups tested in terms of blood vessel quantities. Therefore, our study result is in agreement with both authors since there was no difference in terms of neovascularization.

\section{Granulation tissue}

The groups presented statistical difference at 7 days postsurgery (Figure 2-D) regarding granulation tissue formation. It was observed a greater amount of granulation tissue formation in the Control Group compared to the other groups $(p=0.043)$. No statistical differences were observed among the groups in the other time points $(\mathrm{P}>0.66)$.

According to Carvalho et al. (2011), the secondary intention healing process requires more time than a primary healing process. Also, it requires that the granulation tissue fills up the wound until the original epithelium. After that, contraction and epithelialization occur for wound remodeling. Wound healing process can be delayed when there is persistency of granulation tissue in the area (Masi et al., 2016). In our study, it was observed that healing in the Propolis and Amniotic Membrane Groups took longer. We can speculate that it happened because of a delay in the formation of granulation tissue, since its formation was not observed in these groups at 7 days post-surgery.

Reis Filho et al. (2017) observed that rabbits being prepared for skin grafting with wounds treated with canine amniotic membrane and laser therapy showed an intense inflammatory reaction. Also, the rabbits presented subsequent failure of graft integration and its consequent necrosis in the group that received treatment with amniotic membrane. Therefore, the membrane has no good purpose in healing to generate granulation tissue to receive the graft. In the present study, as well as in the study conducted by Reis Filho et al. (2017), it was observed that the amniotic membrane did not provide significant healing of experimentally induced wounds, even though it has low immunogenicity properties, anti-inflammatory and antibacterial action and stimulates epithelialization (NIKNEJAD et al., 2013).

\section{Reepithelization}

The tested groups showed no significant difference ( $p>0.30$ ) in all assessment periods for the reepithelization variable amnion has properties that can stimulate healing, such as epidermal growth factor (EGF), vascular endothelial growth factor (VEGF), keratinocyte growth factor (KGF) and fibroblast growth factor (bFGF). EGF and KGF stimulate the proliferation and migration of epithelial cells, thus playing a key role in wound regeneration (LITWINIUK; GRZELA, 
2014). In the present study, these factors did not lead to a faster efficient re-epithelialization, since all the groups tested did not show any difference among them.

Our study aimed to observe the effectiveness of alternative methods to accelerate the wound healing process. It is known that propolis and amniotic membrane have already demonstrated good results, as reported by Hozzeinet al. (2015) and Leila et al. (2017), respectively. However, some authors, also, did not observe significant benefits in using these alternative methods. Reis Filho et al. (2017) did not have satisfactory results when using the amniotic membrane. In addition, unsatisfactory results were already obtained using propolis., Oryan, Alemzadeh and Moshiri (2018), mentioned that the specific properties of propolis depend on several factors, mainly its type, flora of the region and color (green and red), requiring more studies on the different concentrations of these alternative method.

The suture points for fixing the amniotic membrane were not removed during the study period. It is known that the nylon thread produces a minimal tissue reaction when used in external sutures, and this reaction increases according to the time it remains in the body (RIBEIRO et al., 2005). This may justify the tissue reaction and the difficulty of reepithelization found in the Amniotic Membrane Group.

After the amniotic membrane had slowed healing process and caused necrosis of some experimentally induced wound areas, Duarte (2007) mentioned the possibility that the preservation in glycerin acts as a dehydrator of the material and a possible irritant to the wound cells. The author speculates that these could be factors with properties to increase local necrosis and cause a delayed re-epithelialization. He also mentions that dehydration causes a decrease in humidity and hinders the growth of cells in the healing area. Therefore, more studies are needed to evaluate the methods of preserving the membrane and its interference in the response of the wounds.

\section{CONCLUSION}

The evaluated treatments were not superior to the to accelerate the healing process. The treatments only positively affected microscopic punctual scores that did not interfere in the macroscopic analysis.

\section{ACKNOWLEDGMENTS}

To the University of Marília - UNIMAR for research grants and scholarship.

\section{REFERENCES}

BARACHO, N.C. et al. Extrato Hidroalcoolico de própolis e cicatrização de feridas no diabetes tipo I: Estudo experimental. Revista Científica Universitas, v. 2, 2016.

BARBOSA, M. H. etal.Ação terapêutica da própolis em lesões cutâneas. Acta Paulista de Enfermagem, v. 22, n. 3, p. 318-322, jun. 2009.

BEHEREGARAY, W. K. etal. Eletroestimulação na cicatrização de feridas cutâneas experimentais em coelhos. Ciência Rural, v. 44, n. 5, 2014.

BOVINO, F. et al. Termografia de feridas experimentais tratadas ou não com membrana amniótica. Revista Acadêmica Ciência Animal, v. 15, n. 2, p. 205-206, 2017.

CARVALHO, D. V.; BORGES, E.L. Tratamento ambulatorial de pacientes com ferida cirúrgica abdominal e pélvica. Revista Mineira de Enfermagem, v. 15, n. 1, p. 25-33, 2011.

DE ALMEIDA, E. B. et al. The incorporation of Brazilian propolis into collagen-based dressing films improves dermal burn healing. Journal Of Ethnopharmacology, v. 147, n. 2, p. 419-425, 2013.

DUARTE, I. G. L. Membrana amniótica como curativo biológico na cicatrização de feridas infectadas: estudo experimental em coelhos. Dissertação (Mestrado) - Universidade Federal de Minas Gerais, Belo Horizonte, 2007.

FERREIRA, A. G. A. Aplicação do laser de baixa intensidade no processo de cicatrização de ferida cirúrgica: padronização dos parâmetros dosimétricos. 2016. 110 f. Dissertação (Mestrado em Engenharia Mecânica) - Universidade Federal de Minas Gerais, Belo Horizonte, 2016.
FREITAS, A. L. Avaliação da cicatrização de feridas por hidrogel contendo extrato seco padronizado de Hyptispectinata (L.) em ratos. 2018. 85 f. Dissertação (Mestrado em Ciências da Saúde) Universidade Federal de Sergipe, Aracaju, 2018.

GARROS, I. C. et al. Extrato de Passiflora edulis na cicatrização de feridas cutâneas abertas em ratos: estudo morfológico e histológico. Acta Cirúrgica Brasileira, v. 21, n. 3, p. 55-65, 2006.

HORTENSIUS, R.A.;EBENS,J.H.;HARLEY,B.A.C. Immunomodulatory effects of amniotic membrane matrix incorporated into collagen scaffolds. Journal of Biomedical Materials Research Part A, v. 104, n. 6, p. 1332-1342, 2016.

HOZZEIN, W. N. et al. Topical Application of Propolis Enhances Cutaneous Wound Healing by Promoting TCF-Beta/Smad-Mediated Collagen Production in a Streptozotocin-Induced Type I Diabetic Mouse Model. Cellular Physiology and Biochemistry, v. 37, п. 3, p.940-954, 2015.

HUNGER, S. et al. Use of amniotic membrane for radial forearm free flap donor site coverage: clinical, functional and cosmetic outcomes. Clinical Oral Investigations, p. 1-11, 15, 2019.

JASTRZęBSKA-STOJKO, Z et al. Biological Activity of PropolisHoney Balm in the Treatment of Experimentally-Evoked Burn Wounds. Molecules, v. 18, n. 11, p. 14397-14413, 2013.

LEILA, G. et al. A randomized trial study on the effect of amniotic membrane graft on wound healing process after anal fistulotomy. Journal of Coloproctology, v. 37, n. 3, p.187-192, 2017. 
LITWINIUK, M.; GRZELA, T. Amniotic membrane: New concepts for an old dressing. Wound Repair and Regeneration, v. 22, n. 4, p.451-456, 2014.

MAMEDE, A. C. et al. Amniotic membrane: from structure and functions to clinical applications. Cell and Tissue Research, v. 349, ก. 2, p.447-458, 2012.

MANDELBAUM, S. H.; DI SANTIS, E. P.; MANDELBAUM, M. H. S. Cicatrização: conceitos atuais e recursos auxiliares - Parte 1. Anais Brasileiro de Dermatologia, v. 78, n. 4, p. 393-410, 2003.

MARINHO, R. C. Efeitos da fotobiomodulação associado ao própolis verde na angiogênese, produção e reorganização do colágeno em feridas cutâneas de ratos diabéticos.2018. $56 \mathrm{f}$. Tese (Mestrado em Biologia Estrutural e Funcional) - Universidade Federal do Rio Grande do Norte, Natal, 2018.

MARQUELE-OLIVEIRA, F.et al. Development, characterization and pre-clinical trials of an innovative wound healing dressing based on propolis (EPP-AF ${ }^{\circledast}$ )-containing self-microemulsifying formulation incorporated in biocellulose membranes. International Journal of Biological Macromolecules, v. 136, p.570-578, 2019.

MARTINS, N. L. P. et al. Análise comparativa da cicatrização da pele com o uso intraperitoneal de extrato aquoso de Orbignya phalerata (Babaçu). Estudo controlado em ratos. Acta cirúrgica brasileira, v. 2l, n. 3, p. 66-75, 2006.

MASI, E. C. D. J. et al. The influence of growth factors on skin wound healing in rats. Brazilian Journal of Otorhinolaryngology, v. 82, п. 5, p. 512-521, 2016.

MOHAMMADI, A. A.; JOHARI, H. G.; ESKANDARI, S. Effect of amniotic membrane on graft take in extremity burns. Burns, v. 39, ก. 6, p.1137-1141, 2013.

MOREIRA, R. T.; OLIVEIRA, B. S.; ROCHA, A. A. Própolis: uma alternativa no tratamento de feridas cirúrgicas em bovinos. Revista Eixo, v. 7, п. 1, 2018.

NIKNEJAD, H. et al. Side dependent effects of the human amnion on angiogenesis. Placenta, v.34, p.340-345, 2013.

NOGUEIRA, S. A. et al. Utilização de própolis verde na cicatrização de lesões cutâneas em ratos. Revista da Universidade Vale do Rio Verde, v. 3, n. 16, p.l-6, dez. 2018.
ORYAN, A.; ALEMZADEH, E.; MOSHIRI, A. Potential role of propolis in wound healing: Biological properties and therapeutic activities. Biomedicine \& Pharmacotherapy, v. 98, p.469-483, fev. 2018.

PACHECO, C. G. P. Avaliação do efeito do laser de baixa intensidade no processo de reparo de alvéolos pós-exodontia tratados com hidroxiapatita e osso bovino inorgânico em ratos. 2016. 79 f. Dissertação (Mestrado em Odontologia) - Universidade Estadual de Ponta Grossa, Ponta Grossa, 2016.

DA PAIXÃO, D. R. et al. Efeitos da própolis na proliferação de fibroblastos em lesões cutâneas de ratos. Revista de Ciências Farmacêuticas Básica Aplicada, v. 3, n. 35, p.413-417, 2014.

PEREIRA, R. F.; BÁRTOLO, P.J. Traditional Therapies for Skin Wound Healing. Advances In Wound Care, v. 5, n. 5, p. 208-229, 2016.

PONTES, K. C. S; BORGES, A. P. B; DUARTE, T. S.; MORATO, G. L.; ZAVAN, V.; ELEOTERIO, R. B.; CARLO, E. C. Membrana amniótica canina utilizada como bandagem en úlcera superficial de córnea de coelhos - aspectos clínicos. Arquivo Brasileiro de Medicina Veterinária e Zootecnia, v. 60, n. 5, p. 1069-1074, 2008.

REIS FILHO, N. P. Comparação entre diferentes ondas de laser e óleo de girassol ozonizado na epitelização de enxertos cutâneos aplicados em feridas recém criadas de coelhos (Oryctolagus cuniculus). 2019. 66 f. Dissertação (Doutorado) - Universidade Estadual Paulista, Jaboticabal, 2019.

REIS FILHO, N. et al. Epitelização de enxertos cutâneos em feridas recentes de coelhos tratados com membrana amniótica canina e/ ou laserterapia. Arquivo Brasileiro de Medicina Veterinária e Zootecnia, v. 69, n. 3, p.603-612, 2017.

RIBEIRO, G. et al. Associação fitoterápica no tratamento de feridas cutâneas induzidas em eqüinos. Arquivo Brasileiro Medicina Veterinária Zootecnia, v.65, n.5, p.1427-1433, 2013.

RIBEIRO, C. M. B. et al. Estudo clínico e histopatológico da reação tecidual às suturas interna e externa dos fios monofilamentares de nylon e poliglecaprone 25 em ratos. Acta Cirurgica Brasileira, v. 20, п. 4, p.284-291, 2005

SUVARNA, K.; MUNIRA, M. Wound healing process and wound care dressing: a detailed review. Journal of Pharma Research, $v$. 2, п. 11, p. 6-12, 2013.

TAGLIARI, E. et al. Efeito da administração oral de probióticos na cicatrização de feridas cutâneas em ratos. Arquivo Brasileiro de Cirurgia Digital, v. 32, п. 3, 2019. 